\title{
Aprotinin and Classic Wound Drainage are Unnecessary in Total Hip Replacement - A Prospective Randomized Trial
}

\author{
F. Fleischmann ${ }^{1 *}$, C. Matuschek ${ }^{2 *}$, K. Orth ${ }^{3 *}$, P. A. Gerber ${ }^{4}$, R. Mota ${ }^{4}$, W. T. Knoefel ${ }^{5}$, M. Peiper ${ }^{5}$, \\ M. Schick ${ }^{1}$, M. van Griensven ${ }^{6}$, E. Bölke ${ }^{1 *}$, W. Fleischmann ${ }^{1 *}$ \\ ${ }^{1}$ Department of Surgery, Krankenhaus Bietigheim- Biesingen, Germany, \\ ${ }^{2}$ Department of Radiation Therapy and Radiation Oncology, University of Düsseldorf, Germany, \\ ${ }^{3}$ Department of Surgery, KRH Hannover, Germany, \\ ${ }^{4}$ Department of Dermatology, University of Düsseldorf, Germany, \\ ${ }^{5}$ Department of Surgery, University of Düsseldorf, Germany, \\ ${ }^{6}$ Ludwig Boltzmann Institute for Experimental and Clinical Traumatology, AUVA Research Center, \\ Austrian Cluster for Tissue Regeneration, Vienna,Austria
}

\begin{abstract}
Background: Classic wound drainage is still common in hip replacement but its benefit is doubtful. The role of systemic administration of proteinase inhibitors like aprotinin to avoid perioperative blood loss is still unclear.

Patients and Methods: In a prospective randomized trial, the perioperative blood loss in alloplastic hip replacement under the influence of proteinase inhibitor (aprotinin, Trasylol ${ }^{\circledR}$ ) using wound drainage as well as compression treatment alone were compared. $80 \mathrm{pa}$ tients were prospectively randomized in 4 arms. Patients received either aprotinin or placebo during surgery as well as drainage or targeted external wound compression.

Results: Observing the "drug therapy" aprotinin had no effect on the intra- or postoperative blood loss $(\mathrm{p}>0.05)$, a trend to lower postoperative hemoglobin decline was found, but without significance. Thrombosis occurred in neither the aprotinin nor in the placebo group. Two patients had a severe allergic drug reaction and were excluded from the study. Under "non drug therapy" with compression therapy and wound drainage a significant difference in blood loss was found $(p<0.001)$. The blood loss was higher under the wound drainage. There was no influence on the infection rate. Yet we could observe increased bruising under the sole external compression treatment.

Conclusion: The administration of aprotinin did not achieve the desired reduction of perioperative blood loss. Hence, costs and two severe allergic drug reactions in our study represent arguments against its use in regular treatment. Furthermore, it seems that wound drainage is neglectable in hip replacement and can be substituted by a sole compression treatment.
\end{abstract}

Key words: total hip replacement, wound drainage, drug reaction, aprotinin, Trasylol ${ }^{\circledR}$, compression treatment

\footnotetext{
$*$ Equal contribution
}

\section{INTRODUCTION}

Surgical dissection of soft tissue and bone in arthroplasty of the hip joint can cause substantial bleeding and is responsible for intra- and postoperative blood loss. The intraoperative blood loss can be reduced by using mainly blunt tissue dissection as far as possible, reduction of tissue trauma, local hypothermia and pharmacological influence on the body's blood coagulation mechanism $[22,42,56]$. Furthermore, the postoperative blood loss is influenced by the effectiveness and durability of the body's own hemostasis, external tissue compression, and particularly by the method of wound drainage. In 1954, the French surgeons Redon, Jost and Torque evacuated glass bottles to promote drainage of wound secretion after surgery. This was the beginning of the era of postoperative suction drains $[7,9,10,12]$.

The idea behind wound drainage is an optimized balance of secretion and accumulation of blood and the internal adaptation and stabilization of wounds. Over the years, the drainage technique developed with various modifications [18-21, 23, 25]. Aiming to avoid postoperative complications and to provide additional positive effects on wound healing, the postoperative secretion drainage using Redon drains is now a standard method for European Orthopaedic-Trauma surgeons [15]. However, there are serious numbers of complications possibly caused by wound drainage [24, 26, 29, 31].

One major disadvantage is the risk for retrograde wound contamination with bacteria. Other reasons are the cytoadhesive properties of polymeric drainage systems, increased postoperative blood loss caused by the contact of the drains with tissue surfaces. There are also arguments of injured vessels and impairment of wound healing through foreign body reaction as well as the release of toxic plasticizers, especially when using drainage made of polyvinyl chloride [24, $26,31,32]$. Concomitantly, numerous studies have addressed the positive effects of a drainage free surgical 
technique $[15,21,28,34]$. These results show that wound drainage can be waived for certain surgical procedures without the risk of impaired wound healing. The question is whether the prophylactic use of suction drains for the patient really is an important procedure to prevent complications or whether it increases the risk for postoperative blood loss and wound infections [32].

Another cause of increased blood loss in arthroplasty can be an imbalance in the hemostasis system $[29,61]$. Tissue injury induces the release of proteolytic substances which increase fibrinolysis, leading to a relative lack of endogenous proteinase inhibitors like $\alpha$-antiplasmin and $\alpha$-macroglobulin. The proteinase inhibitor aprotinin (Trasylol ${ }^{\circledR}$ Bayer, Germany) interrupts this mechanism, as it interferes in regulating the mechanisms of bleeding and thereby may reduce perioperative blood loss. Aprotinin, a kallikrein inactivator, was discovered in 1930. It was isolated in 1936 as a trypsin inhibitor by Kunitz and Northrop from bovine tissue $[4,5,35,40]$. These results have been confirmed by many studies showing that aprotinin is able to inhibit a variety of proteinases. Royston and co-workers showed that high doses of aprotinin during cardiac surgery significantly reduced blood loss [50]. Although this effect was achieved through an inhibition of fibrinolysis, there was no increased rate of thrombosis. These results triggered a growing interest in aprotinin and led to a number of studies in cardiac-, vascular-, liver- and in orthopedic surgery [3-5, 11].

The investigation of our study was whether there is a need for suction wound drainage in cement less hip replacement im comparison of wound compression. On the other hand, we sought to analyze whether an intraoperative administration of proteinase inhibitors like aprotinin may lead to a reduction of the perioperative blood loss.

\section{Patients, Materials and Methods}

In a prospective randomized study, patients older than 18 years undergoing elective implantation of cement less arthroplasty of the hip due to manifest coxarthrosis were included (Fig. 1). The study was approved by the local Ethics Committee. Patients with a known intolerance to aprotinin, pre-existing coagulation disor- ders or undergoing drug therapy for regulating coagulation were excluded from the study.

The study was a prospective, randomized doubleblind parallel trial with 4 arms comparing 80 patients (intention to treat) (51-80 years, 43 o, $\left.38 \sigma^{\prime \prime}\right)$. We compared Trasylol ${ }^{\circledR}$ against placebo in one trial and suction drains versus external compression on the other. All patients were exclusively treated by 2 experienced surgeons participating in earlier studies. Drugs consumed by the patients on admission and during the course of the study were recorded as adjunctive therapy in the protocol. Adverse events between consent and beginning of the studyand the causality between event and study procedure were documented. Undercurrent diseases and manifestations were considered as "adverse events" and were reported. In totally $80 \mathrm{pa}-$ tients could be included for the trials. From this overall population group, $2 \times 40$ patients were randomized receiving either for receiving intraoperative $250 \mathrm{ml}$ of a solution containing $500 \mathrm{kU}$ of Trasylol ${ }^{\circledR}$ or $250 \mathrm{ml}$ $0.9 \% \mathrm{NaCl}$ as a placebo. In addition, each group was subdivided into two arms, either with wound drainage by suction drainages, $(n=20)$ or with a specific external wound compression $(n=20)$ (Fig. 2).

The implantation of cement less hip arthroplasty type Zweymüller was carried out on the transgluteal access according to the Bauer procedure.

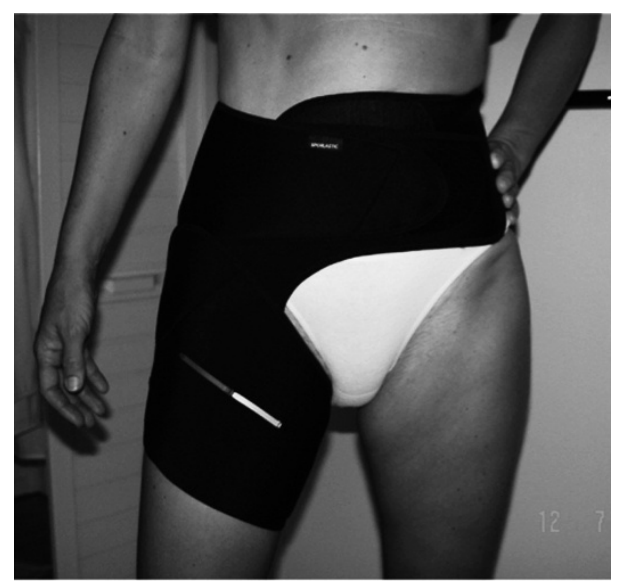

Fig. 2. External wound compression in a patient.

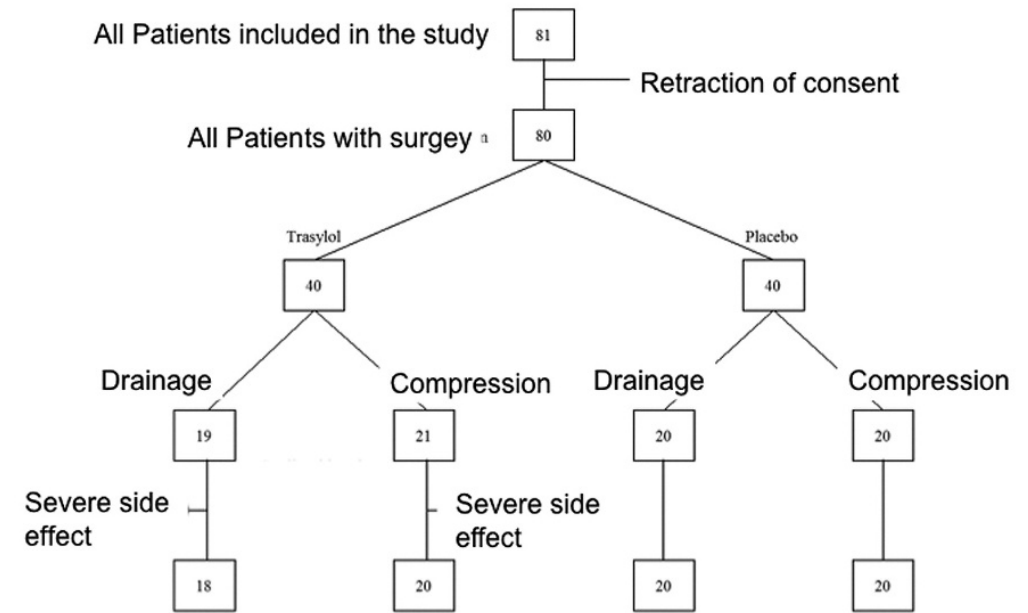

Fig. 1. Study design. 
At the end of the operation, the surgeon received the randomized information whether the wound should be treated with two (subcutaneous and subfascial located) suction "Redon" drains or with external compression (Fig. 2). Drains were removed at the $2^{\text {nd }}$ postoperative day. There was a daily inspection and clinical documentation of the wound healing.

\section{Diagnostic Tests}

\section{Loss of blood}

A main objective of this study was to analyze the amount of perioperative blood loss, resulting from the intraoperative blood loss, blood loss via wound drainage and the size of the hematoma constituted at the wound area.

The intraoperative blood loss was calculated based on the collected amount of fluid. The intraoperative administered amount of volume of Ringer's solution was subtracted from the total amount of fluid trapped. Therefore all swabs and tissues were weighed pre- and postoperatively. The difference between the pre-operative and postoperative weight was divided by the specific gravity of blood $(1.06 \mathrm{mg} / \mathrm{ml})$. For all patients with suction drains, the entire post-operative blood loss of suction bottle was documented.

All patients received ultrasound (US) diagnostic by the same examiner screening for hematoma at the $2^{\text {nd }}$ and $14^{\text {th }}$ postoperative day. The volume of the detected hematomas by US performed was added to the perioperatively counted loss of blood.

Blood samples were drawn for every patient preoperatively and at the $1^{\text {st }}$ and $2^{\text {nd }}$ postoperative day. Blood transfusions were performed and documented according to the approved study protocol $(\mathrm{Hb}<8$ $\mathrm{mg} / \mathrm{l})$. All patients received a duplex ultrasound to exclude or objective venous thrombosis on the $2^{\text {nd }}$ postoperative day.

\section{STATISTICS}

The influence of two factors- "drug-" (aprotinin/ placebo) and "non drug therapy" (drainage/compression) - were examined.

Data collection was carried out with the spreadsheet program Excel and data processing with the statistical programs SAS and SPSS Version 16. All data were collected in boxplots and the median was described.

The significance level was set at $\mathrm{p}<0.05$. Comparison of the groups was descriptive for important parameters such as age and gender. A two-way analysis of variance was performed for the total blood loss and exploratory at first for hemoglobin and the $2^{\text {nd }}$ postoperative day, respectively. The analysis of variance was tested for interactions.

\section{RESULTS}

Each group of patients was equal concerning the demographic data. Two patients, one in the drainage and one in the compression group developed a severe allergic reaction after Trasylol $^{\circledR}$ medication and were excluded from further analysis, resulting in a final population of 78 patients.

\section{INTRAOPERATIVE BLOOD LOSS}

The patients in the Trasylol ${ }^{\circledR}$ group $(\mathrm{n}=37)$ reached a median blood loss of $507 \mathrm{ml}(123-1141 \mathrm{ml})$. The median blood loss in the placebo group $(\mathrm{n}=40)$ was 517 $\mathrm{ml}(132-1226 \mathrm{ml})$. In comparison of the medians patients with Trasylol ${ }^{\circledR}$ lost $10 \mathrm{ml}$ more blood perioperatively than patients with a $\mathrm{NaCl}$ the placebo, the latter had a larger range. These results were however not statistically significant.

\section{Blood Loss through the Suction Drains}

18 patients with intraoperative drainage receiving Trasylol ${ }^{\circledR}$ had a median blood loss of $620 \mathrm{ml}(190-1525$ ml). 20 patients with intraoperative $\mathrm{NaCl}$ placebo lost a median of $615 \mathrm{ml}(100-1260 \mathrm{ml})$ blood, resulting in a median of $5 \mathrm{ml}$ less blood loss in the Trasylol ${ }^{\circledR}$-treated group.

\section{SOFT TISSUE SONOGRAPHY}

In one patient of the Trasylol ${ }^{\circledR} /$ drainage group, a hematoma with the size of $12.3 \mathrm{ml}$ on the $2^{\text {nd }}$ postoperative day was observed, which did not further increase $(5.6 \%, 1 / 18)$.

In one patient in the Trasylol ${ }^{\circledR} /$ compression group, $^{2}$ a hematoma with a size of $32.6 \mathrm{ml}$ on the $2^{\text {nd }}$ postoperative day developed, which was reduced on the 14 th postoperative day to $14.4 \mathrm{ml}(5 \%, 1 / 20)$.

In the placebo/drainage group 4 patients showed hematomas in the operated wound area, 3 hematomas of $10.5 \mathrm{ml}, 11.8 \mathrm{ml}$ and $7.4 \mathrm{ml}$ were found on the $2^{\text {nd }}$ postoperative day. One hematoma increased in fourteen days to a size of $32.6 \mathrm{ml}$. Furthermore, one hematoma was diagnosed on the $8^{\text {th }}$ postoperative day with bleeding after drainage removal at the $2^{\text {nd }}$ postoperative day. One patient, whose examination was without result on the $2^{\text {nd }}$ postoperative day, developed on the $14^{\text {th }}$ postoperative day a hematoma of $11.8 \mathrm{ml}$. $(20 \%, 4 / 20)$.

Five hematomas (average size $18.7 \mathrm{ml}$, range 10.0 35.2 ) in the placebo group/ compression group were diagnosed on the second postoperative day, one of these increased in fourteen days to a size of $14.3 \mathrm{ml}$. On the $14^{\text {th }}$ postoperative day, bruises of $25.0 \mathrm{ml}$ and $12.5 \mathrm{ml}$ were seen in two patients $(35 \%, 7 / 20)$.

Summarized, the Trasylol ${ }^{\circledR} /$ Redon group showed the lowest number of total hematoma.

\section{Perioperative Blood Loss}

Patients in the Trasylol $^{\circledR} /$ drainage arm $(\mathrm{n}=18)$ showed a median blood loss of $1201 \mathrm{ml}$ (704-1648 $\mathrm{ml}$ ). Oppositely, the Trasylol ${ }^{\circledR} /$ compression group ( $\mathrm{n}$ $=20$ ), presented with a median blood loss of $596 \mathrm{ml}$ (245-1141 ml). The blood loss in the placebo/drainage group $(\mathrm{n}=20)$ had a median of $1223 \mathrm{ml}(592-1756$ $\mathrm{ml})$, while in the placebo/compression group $(\mathrm{n}=20)$ a median blood loss of $554 \mathrm{ml}$ (143-1063 ml) was measured.

The blood loss under the influence of the "drug therapy" with Trasylol ${ }^{\circledR}$ was not significantly different from placebo $(\mathrm{p}=0.7540)$. 


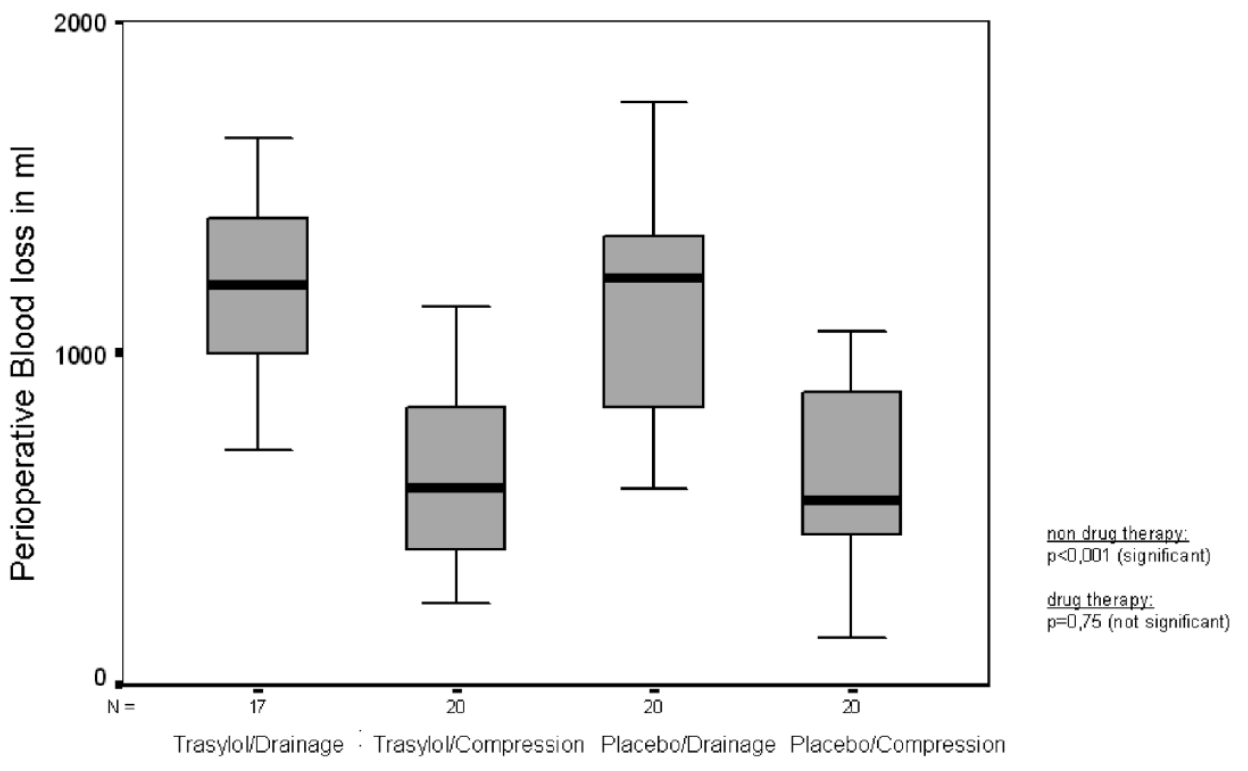

Fig. 3. Box and Whisker Plot of the perioperative blood loss. The upper line of the box shows the $75 \%$ quartile of all values, the lower line the $25 \%$ quartile. The line in the middle of the box is the median.

\section{Group}

On the other hand the ,non drug therapy“ showed a significantly higher blood loss in the wound treatment with suction drainage instead of compression $(\mathrm{p}<0.001)$.

\section{BLOOD TRANSFUSION}

In the Trasylol ${ }^{\circledR} /$ Redon group $(n=18), 10$ patients required blood transfusions within 48 hours (56\%), while 7 out of 20 patients $(35 \%)$ from the Trasylol ${ }^{\circledR} /$ compression group required a blood transfusion ( $\mathrm{p}=$ $0.02)$. Similar, in seven out of 20 patients $(35 \%)$ in the placebo/Redon group, blood transfusion was performed, while nine of 20 patients $(45 \%)$ in the placebo/compression group needed a blood transfusion. Variance and interaction analysis of variance showed a significant interaction regarding higher blood loss in the "non-drug therapy" with suction drainage ( $p$ $<0.001)$ in contrast to compression. Through the application of Trasylol $^{\circledR}$ the blood loss did not change significantly $(p=0.75)$. Interactions were not detectable $(p=0.74)$. A re-analysis of variance with neglect of the interaction analysis showed a significantly higher blood loss through the use of suction drains ( $p<0.001)$, for the factor 'non-drug therapy' but for the medical treatment no statistically significant change after Trasylol ${ }^{\circledR}$ application was observed $(p=0.75)$.

\section{ERYTHROCYTES}

The mean of erythrocyte concentration of the Trasylol ${ }^{\circledR} /$ drainage group $(n=18)$ was preoperatively $4.1 \mathrm{x}$ $106 / \mu \mathrm{l}\left(3.6-5.0 \times 10^{6} / \mu \mathrm{l}\right)$, decreased on the 1 st postoperative day to $3.5 \times 10^{6} / \mu \mathrm{l}\left(2.8-4.0 \times 10^{6} / \mu \mathrm{l}\right)$ and remained constant on the 2 nd postoperative day with $3.5 \times 10^{6} / \mu \mathrm{l}(2.8$ to $4.1 \times 106 / \mu \mathrm{l})$.

For the Trasylol ${ }^{\circledR} /$ compression group $(\mathrm{n}=20)$, the mean of preoperative red blood cell concentration was $4.2 \times 10^{6} / \mu \mathrm{l}\left(3,4-5,0 \times 10^{6} / \mu \mathrm{l}\right)$, decreased on the $1 \mathrm{st}$ postoperative day to $3.6 \times 10^{6} / \mu \mathrm{l}\left(1.8-4.2 \times 10^{6} / \mu \mathrm{l}\right)$ and on the 2 nd postoperative day to $3.5 \times 10^{6} / \mu l(2.8$ to $\left.4.1 \times 10^{6} / \mu \mathrm{l}\right)$.

Preoperatively, the mean erythrocyte concentration of the group placebo/drainage $(\mathrm{n}=20)$ was $4.4 \mathrm{x}$ $106 / \mu \mathrm{l}\left(3.5-5.0 \times 10^{6} / \mu \mathrm{l}\right)$, decreased to on the $1 \mathrm{st}$ postoperative day to $3.3 \times 10^{6} / \mu \mathrm{l}\left(2.9\right.$ to $\left.4.1 \times 10^{6} / \mu \mathrm{l}\right)$ and remained unchanged on the 2 nd postoperative day with $3.3 \times 10^{6} / \mu \mathrm{l}(2.7$ to $3.9 \times 106 / \mu \mathrm{l})$.

The mean of erythrocyte concentration in the placebo group/compression $(\mathrm{n}=20)$ was preoperatively $4.3 \times 10^{6} / \mu \mathrm{l}\left(3.3\right.$ to $\left.5.2 \times 10^{6} / \mu \mathrm{l}\right)$ and felt at the first postoperative days to $3.4 \times 10^{6} / \mu \mathrm{l}(2.7-4.0 \mathrm{x}$ $10^{6} / \mu \mathrm{l}$ ) and on the 2 nd postoperative day to $3.1 \mathrm{x}$ $10^{6} / \mu \mathrm{l}\left(2.6\right.$ to $\left.3.9 \times 10^{6} / \mu \mathrm{l}\right)$.

Patients treated with Trasylol ${ }^{\circledR}$ had a smaller postoperative decrease in red cell concentration than the placebo groups. The highest difference was found on the first postoperative day.

\section{HeMoglobin}

Figure 4 shows a lower postoperative decline in hemoglobin values in the Trasylol groups. The difference is not significant.

\section{INFECTION RATE}

We could not find a difference in the infection rate in all groups.

\section{CoAgulation}

The postoperative coagulation values are shown in Figure 5. No significant difference was detected between the Trasylol ${ }^{\circledR}$ and the placebo group.

\section{Platelet Concentration}

Figure 6 shows the platelet concentration before and after surgery. No significant difference was detected between the Trasylol ${ }^{\circledR}$ and the placebo group. 

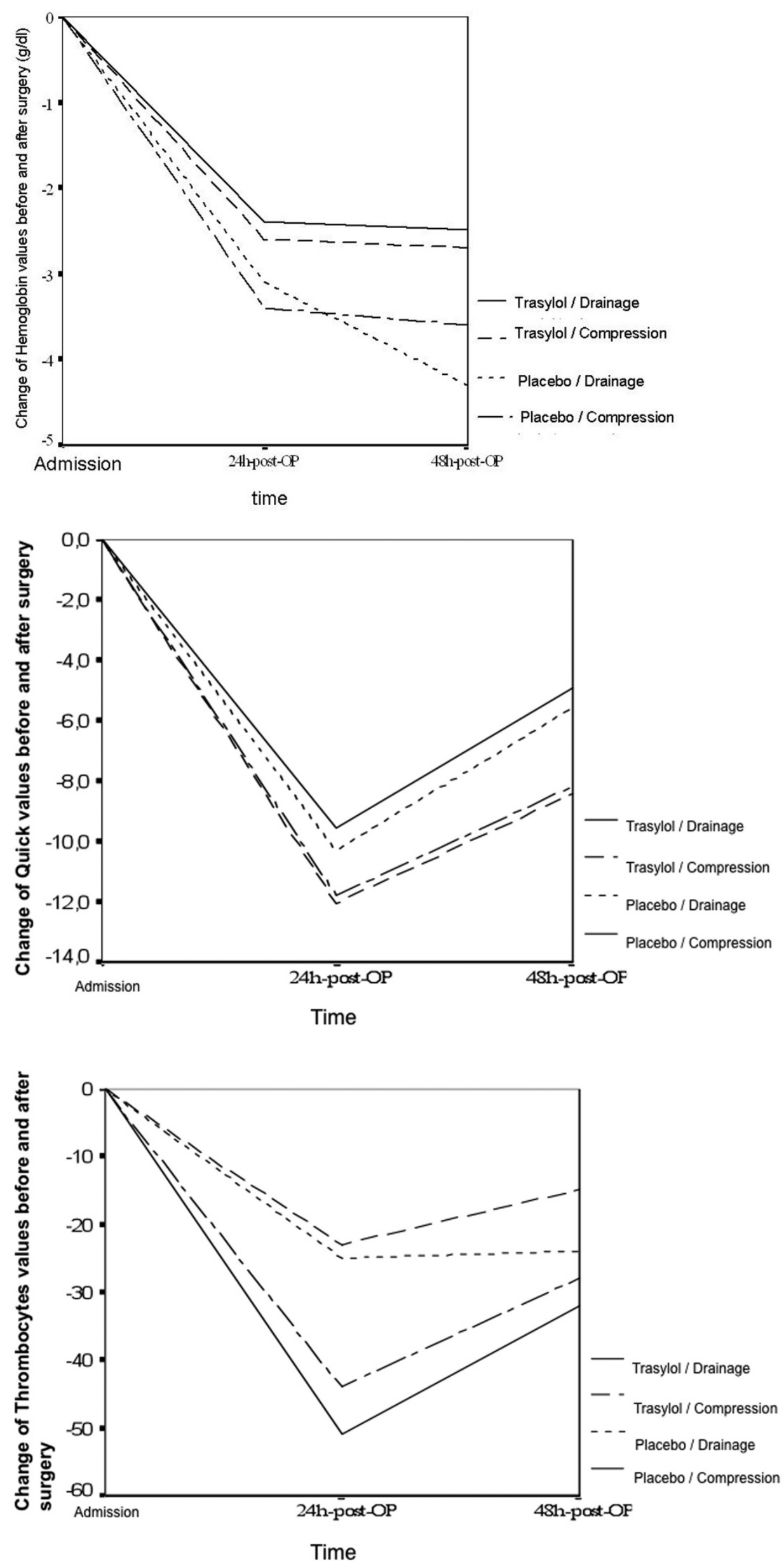

Fig. 4. Postoperative decline in hemoglobin values.

Fig. 5. Postoperative changes of Quick values of each group in relation to baseline.
Fig. 6. Postoperative changes in platelet concentration of each group in relation to baseeach
line. 
Adverse Events

In the Trasylol ${ }^{\circledR} /$ drainage and Trasylol ${ }^{\circledR} /$ compression group, one patient each showed an allergic reaction to Trasylol ${ }^{\circledR}$ and was excluded from the study. In the placebo/drainage group, one patient developed a postoperative hematoma which had to be drained surgically on the $8^{\text {th }}$ postoperative day with consequent removal of the prosthesis due to wound infection. The further course of this patient was uneventful. Another patient had the drainage removed due to abundant secretion from the wound. The further postoperative clinical course was uneventful. In the placebo/ compression group, one patient developed a large postoperative hematoma which was growing in size and was initially treated conservatively. Since a dislocation of the prosthesis occurred during mobilization revision of the hip with prosthesis changes was performed at $6^{\text {th }}$ postoperative day. The further course was uneventful. In another patient a bad-fit brace had to be removed after 24 hours. In the further course no additional complications occurred.

\section{Discussion}

The extent of perioperative blood loss is undoubtedly an important aspect of surgical quality. The objective of operative drainage is to avoid the loss of blood and wound fluid. Yet, these can be a potential breeding ground for bacteria or inhibit adequate wound healing. In recent years, the routine use of wound drainage was questioned due to a lack of data on the benefit of the drainage of blood or secretions on wound healing. Moreover, several publications suggest that wound drainage can result in an increased hemoglobin drop with a higher rate of blood transfusions, especially in endoprosthetic surgery of the knee or hip joint. In a retrospective study of 364 patients with a hip prosthesis implantation, Hallstrom and Steele compared wound drainage with wound compression and found a significant higher difference in blood loss for the drainage group [21]. Ritter et al. demonstrated that total hip replacement with drainage increased transfusion volume on an average of $95 \mathrm{ml}$ of blood per patient as compared to total hip replacement without drainage [49]. However, no increased transfusion requirements were documented after implantation of knee replacement. A retrospective study by Reilly et al. for knee replacement revealed a significant decline in hemoglobin and a significantly higher transfusion rate in patients with wound drainage [47].

In this study, we demonstrated that the blood loss in the suction drainage group was about $500 \mathrm{ml}$ per patient higher than in the compression group. It has to be noted that the blood loss via the drains, underwent a degree of dilution by serous tissue fluid. Determination of hematocrit in the defect is a more accurate detection for blood loss. With regard to systemic hemoglobin, no statistically significant difference between the drainage and compression groups was evident and no hemoglobin decline was found in any group postoperatively. The higher blood loss rate of the drainage group did not translate into hemoglobin decreases. However, this rather reflects the behavior of the hos- pital transfusion rules than the actual blood loss. In not drained wounds more ecchymoses occur. Hallstrom and Steele reported a hematoma rate in the undrained wounds of $11.4 \%$ versus $2.3 \%$ in drained wounds and Holt et al. describe 69\% versus 39\% [21]. In addition, secondary hematomas have been described after removal of drains. Werner et al. attributes this to the destruction of vascular structures, which are attracted to the vacuum in the lumen of the drainage [58]. Kirschner, Wolter and Tittel et. al. showed that the drains under "high vacuum" conditions (about $80 \mathrm{kPa}$ ) are just of short time use, since the lumen of the drainage tube is quickly occluded by aspirated tissue $[31,55,60]$. Parker suggests that the hematoma rate is not affected by drainage [43]. Even in our study we found a hemato-seroma one week after the removal of the drainage tube .

An additional parameter for measuring the total postoperative blood loss was ultrasound examination of the wound area, which allows a reasonable estimate of any fluid collection. In our study we did not find hematoma as frequently in the compression group as compared to the drainage group.

Bacteria show a high affinity to polymeric materials. In fact, they produce a biofilm that firmly adheres to the plastic structure. Herein, drains serve as a kind of an entry into the wound area, representing a potential risk factor for an increased postoperative infection rate, which we could not find in our study [24-26, 31, 32]. This reflects the ambivalence between sensible drainage of wound secretion and potential risk of infection which asks for appropriate hygiene when changing wound dressings and limited duration of drainage therapy. Willett et al. found a colonization of the wound fluid at the free end of the drainage tube in $6 \%$ of patients $(\mathrm{n}=120)$ [59]. Also Knapp et al. reported a contamination of $14.4 \%$ of all drainage tubes, while the aspirated wound fluid was infected in only $7.4 \%$ [32]. With regard to the incidence of wound infections in drained and non-drained wounds no significant difference was found in our study. This result correlates with the literature, stating that the perioperative infection risk and wound healing are not affected by dropping the existence of postoperative wound drainage. With sufficient postoperative tissue compression and venous thrombosis prophylaxis (thus increasing venous return and hemostasis) unimpeded wound healing can be expected. This mechanical way of hemostasis counteracts the formation of hematomas, thus making a contribution to an undisturbed wound healing. The compression of the wound increases the local pressure gradient in the tissue and causes a redistribution of water as an anti-edematous effect. However, compression may cause serious complications. Shall et al. conducted that a too tight compression may aggravate chronic arterial occlusive disease up to ischemia, resulting in pain and eventually irreparable tissue damage [58]. Similarly, a localized compression such as a drastic pressure bandage may cause venous stasis, which paradoxically increases the risk of straight bleeding and thromboembolic complications. A correct bandaging technique should achieve a uniformly increasing pressure gradient from proximal to distal on the extremity, resulting in prophylaxis 
of thrombosis, hemostasis and prevention of edema. In our study, we used ProThera-Hüftorthesen (PolyMedics, Peer Belgium), which were individually adapted preoperatively to patients' proximal thigh.

Only once the brace had to be removed because of pain and a loose fit after 24 hours. In comparison to winding compression bandages, the procedure was perceived by patients as comfortable and gave stabilizing. Even in the absence of drainage therapy, there was no increase in the rate of hematoma. Additionally, there was a reduction of postoperative blood loss.

Furthermore, we investigated the effect of aprotinin on perioperative blood loss. Recent research results from cardiovascular and orthopedic surgery, a described reduction in perioperative blood loss due to aprotinin medication has been described [4-6]. The antifibrinolytic effect of aprotinin raises the question of favoring intravascular thrombosis. In formal testing, no significantly increased rates of thrombosis have been shown. One explanation for this is that aprotinin causes a stabilization of the platelet membranes. This results in inhibition of thromboxan release and platelet aggregation which counteracts clot formation.

The desired hemostasis by aprotinin is therefore not associated with increased thrombogenesis and does not increase the thromboembolic risk. This concept is in line with our study, as we did not find any evidence of any aprotinin induced increase thrombotic events. However, it is important to note that only clinically manifest thromboses were recorded, a targeted search, with the help of a venography was not performed routinely.

Murkin et al. investigated in several studies the impact and side effects of aprotinin in surgical procedures $[39,40]$. With bilateral implantation of hip joint prostheses or hip arthrodeses the average blood loss was reduced by Trasylol ${ }^{\circledR}$ from $2098 \mathrm{ml}$ to $1498 \mathrm{ml}$, without increased incidence of deep venous thrombosis. Also Samama and Leche et al. obtained in their studies a similar result regarding the influence of aprotinin in orthopedic surgery a similar result [51, 52]. Similarly Jeserschek et al. could show in a prospective randomized study a significant reduction of blood loss after administration of high dose aprotonin when performing hip and knee replacements and excisions of soft tissue sarcoma [29].

On the other hand, Kasper et al. didn't find a reduction in blood loss by aprotinin medication in arthroplasties of the hip [30, 35]. Our own study provided a similar result, since with aprotinin treatment the overall blood loss was not affected. The difference in total blood loss between Trasylol ${ }^{\circledR}$ and placebo groups was clinically insignificant and without statistical significance. Aprotinin had no discernible effect on the amount of transfused blood.

Meanwhile, despite the possibility of a modest reduction in the risk of massive bleeding, the strong and consistent negative mortality trend associated with aprotinin, as compared with the lysine analogues, precludes its use in high-risk cardiac surgery. Following the results of the "BART trial" the manufacturer has withdrawn Trasylol ${ }^{\circledR}$ from the market. $[1,2,8,13,14,16,17,27$, $33,36-38,41,44-46,48,53,54,57]$ Even in our study two patients developed severe allergic side effects.

\section{CONCLUSION}

Our study shows that the blood loss in hip surgery is not reduced by the use of aprotinin. Furthermore it seems that wound drainage is not necessary when an external compression of the wound is performed.

Acknowledgement: This work is dedicated to Thomas and Anni Speer

\section{REFERENCES}

1. Augoustides J. G., On-pump versus off-pump CABG. N Engl J Med. 2010. 362: 852; author reply 853-854.

2. Avorn J., Dangerous deception--hiding the evidence of adverse drug effects. N Engl J Med, 2006. 355: 21692171.

3. Baubillier E., Cherqui D., Dominique C., Khalil M., Bonnet F., Fagniez P. L.Duvaldestin P., A fatal thrombotic complication during liver transplantation after aprotinin administration. Transplantation, 1994. 57: 1664-1666.

4. Bidstrup B. P., Royston D., Taylor K. M.Sapsford R. N., Effect of aprotinin on need for blood transfusion in patients with septic endocarditis having open-heart surgery. Lancet, 1988. 1: 366-367.

5. Bidstrup B. P., Underwood S. R., Sapsford R. N.Streets E. M., Effect of aprotinin (Trasylol) on aorta-coronary bypass graft patency. J Thorac Cardiovasc Surg, 1993. 105: 147-152; discussion 153.

6. Bohrer H., Fleischer F., Lang J.Vahl C., Early formation of thrombi on pulmonary artery catheters in cardiac surgical patients receiving high-dose aprotinin. J Cardiothorac Anesth, 1990. 4: 222-225.

7. Browett J. P., Gibbs A. N., Copeland S. A.Deliss L. J., The use of suction drainage in the operation of meniscectomy. J Bone Joint Surg Br, 1978. 60-B: 516-519.

8. Brown J. R., Birkmeyer N. J.O'connor G. T., Aprotinin in cardiac surgery. N Engl J Med, 2006. 354: 1953-1957; author reply 1953-1957.

9. Brueggemann P. M., Tucker J. K.Wilson P., Intermittent clamping of suction drains in total hip replacement reduces postoperative blood loss: a randomized, controlled trial. J Arthroplasty, 1999. 14: 470-472.

10. Burri C., [Surgical suction drains. A comment on the paper by H. Lohfert (author's transl)]. Unfallheilkunde, 1980. 83: 377-379.

11. Capdevila X., Calvet Y., Biboulet P., Biron C., Rubenovitch J.D'athis F., Aprotinin decreases blood loss and homologous transfusions in patients undergoing major orthopedic surgery. Anesthesiology, 1998. 88: 50-57.

12. Cobb J. P., Why use drains? J Bone Joint Surg Br, 1990. 72: 993-995.

13. D'ambra M. N., Aprotinin in cardiac surgery. N Engl J Med, 2006. 354: 1953-1957; author reply 1953-1957.

14. Drazen J. M., Research replication. N Engl J Med, 2006. 355: 2252-2253.

15. Esler C. N., Blakeway C.Fiddian N. J., The use of a closed-suction drain in total knee arthroplasty. A prospective, randomised study. J Bone Joint Surg Br, 2003. 85: 215-217.

16. Fergusson D. A., Hebert P. C., Mazer C. D., Fremes S., Macadams C., Murkin J. M., Teoh K., Duke P. C., Arellano R., Blajchman M. A., Bussieres J. S., Cote D., Karski J., Martineau R., Robblee J. A., Rodger M., Wells G., Clinch J.Pretorius R., A comparison of aprotinin and lysine analogues in high-risk cardiac surgery. N Engl J Med, 2008. 358: 2319-2331.

17. Ferraris V. A., Bridges C. R.Anderson R. P., Aprotinin in cardiac surgery. N Engl J Med, 2006. 354: 1953-1957; author reply 1953-1957. 
18. Gerngross H.Engler V., [Gravity drainage versus suction drainage: an experimental and clinical study]. Unfallchirurg, 1989. 92: 37-42.

19. Gerngross H., Marquardt K. J., [What suction drainage is optimal for drainage of wound secretion? A clinico-experimental study exemplified by the knee joint]. Chirurg, 1992. 63: 447-453.

20. Gerngross H., Willy C. Walter W. M., [Experimental and clinical studies of the use of thin-lumen polyurethane gravity drainage in accident surgery]. Unfallchirurg, 1992. 95: 21-30.

21. Hallstrom B. R.Steele J. F., Postoperative course after total hip arthroplasty: wound drainage versus no drainage. Orthop Rev, 1992. 21: 847-851.

22. Hananouchi T., Saito M., Koyama T., Sugano N.Yoshikawa H., Tailor-made Surgical Guide Reduces Incidence of Outliers of Cup Placement. Clin Orthop Relat Res. 468: 1088-1095.

23. Harle A., [Postoperative wound suction drainage and its effect on wound healing]. Z Orthop Ihre Grenzgeb, 1985. 123: 395-402.

24. Harle A., [Weaknesses of conventional drainage systems]. Z Orthop Ihre Grenzgeb, 1989. 127: 513-517.

25. Harle A., [Wound drainage]. Hefte Unfallheilkd, 1982. 158: 491-501.

26. Harle A., Ritzerfeld W. R.Linnenbaum F. J., [Bacterial studies of wound and drainage systems and their correlation with clinical findings]. Z Orthop Ihre Grenzgeb, 1983. 121: 584-592.

27. Hiatt W. R., Observational studies of drug safety--aprotinin and the absence of transparency. N Engl J Med, 2006. 355: 2171-2173.

28. Holt B. T., Parks N. L., Engh G. A.Lawrence J. M., Comparison of closed-suction drainage and no drainage after primary total knee arthroplasty. Orthopedics, 1997. 20: 1121-1124; discussion 1124-1125.

29. Jeserschek R., Clar H., Aigner C., Rehak P., Primus B.Windhager R., Reduction of blood loss using high-dose aprotinin in major orthopaedic surgery: a prospective, double-blind, randomised and placebo-controlled study. J Bone Joint Surg Br, 2003. 85: 174-177.

30. Kasper S. M., Elsner F., Hilgers D., Grond S.Rutt J., A retrospective study of the effects of small-dose aprotinin on blood loss and transfusion needs during total hip arthroplasty. Eur J Anaesthesiol, 1998. 15: 669-675.

31. Kirschner P., Romer H.Werner H. P., [Complications of Redon drainage following hip joint replacement operations--an analysis of the causes]. Unfallchirurgie, 1989. 15: 24-31.

32. Knapp U., Sander J.Vieweg K., [Bacteriological study of redon drains in accident surgery (author's transl)]. Dtsch Med Wochenschr, 1975. 100: 10-13.

33. Kumar P. D., Prevention and treatment of major blood loss. N Engl J Med, 2007. 357: 1260-1261; author reply 1261.

34. Labek G.Bohler N., [Blood transfusion in total hip endoprosthesis operations in relation to Redon drainage and pressure bandages. An innovation in surgical method]. Z Orthop Ihre Grenzgeb, 1998. 136: 433-438.

35. Langdown A. J., Field J., Grote J.Himayat H., Aprotinin (Trasylol) does not reduce bleeding in primary total hip arthroplasty. J Arthroplasty, 2000. 15: 1009-1012.

36. Levy J. H., Ramsay J. G.Guyton R. A., Aprotinin in cardiac surgery. N Engl J Med, 2006. 354: 1953-1957; author reply 1953-1957.

37. Mangano D. T., Rieves R. D.Weiss K. D., Judging the safety of aprotinin. N Engl J Med, 2006. 355: 2261 2262.

38. Mangano D. T., Tudor I. C.Dietzel C., The risk associated with aprotinin in cardiac surgery. N Engl J Med, 2006. 354: 353-365.
39. Murkin J. M., Haig G. M., Beer K. J., Cicutti N., Mccutchen J., Comunale M. E., Hall R.Ruzicka B. B., Aprotinin decreases exposure to allogeneic blood during primary unilateral total hip replacement. J Bone Joint Surg Am, 2000. 82: 675-684.

40. Murkin J. M., Shannon N. A., Bourne R. B., Rorabeck C. H., Cruickshank M.Wyile G., Aprotinin decreases blood loss in patients undergoing revision or bilateral total hip arthroplasty. Anesth Analg, 1995. 80: 343-348.

41. Myles P. S., Aprotinin and lysine analogues in high-risk cardiac surgery. N Engl J Med, 2008. 359: 1181; author reply 1181-1182.

42. Neviaser A. S., Chang C., Lyman S., Della Valle A. G.Haas S. B., High incidence of complications from enoxaparin treatment after arthroplasty. Clin Orthop Relat Res 2010. 468: 115-119.

43. Parker M. J., Roberts C. P.Hay D., Closed suction drainage for hip and knee arthroplasty. A meta-analysis. J Bone Joint Surg Am, 2004. 86-A: 1146-1152.

44. Porte R. J., Mallette S. V.Burroughs A. K., Aprotinin and lysine analogues in high-risk cardiac surgery. N Engl J Med, 2008. 359: 1181; author reply 1181-1182.

45. Ray W. A., Learning from aprotinin--mandatory trials of comparative efficacy and safety needed. N Engl J Med, 2008. 358: 840-842.

46. Ray W. A.Stein C. M., The aprotinin story--is BART the final chapter? N Engl J Med, 2008. 358: 23982400.

47. Reilly T. J., Gradisar I. A., Jr., Pakan W.Reilly M., The use of postoperative suction drainage in total knee arthroplasty. Clin Orthop Relat Res, 1986: 238-242.

48. Rieves R. D.Weiss K. D., Judging the safety of aprotinin. N Engl J Med, 2006. 355: 2262.

49. Ritter M. A., Keating E. M. Faris P. M., Closed wound drainage in total hip or total knee replacement. A prospective, randomized study. J Bone Joint Surg Am, 1994. 76: 35-38.

50. Royston D., High-dose aprotinin therapy: a review of the first five years' experience. J Cardiothorac Vasc Anesth, 1992. 6: 76-100.

51. Samama C. M., A direct antifibrinolytic agent in major orthopedic surgery. Orthopedics, 2004. 27: s675-680.

52. Samama C. M., Langeron O., Rosencher N., Capdevila X., Rouche P., Pegoix M., Berniere J.Coriat P., Aprotinin versus placebo in major orthopedic surgery: a randomized, double-blinded, dose-ranging study. Anesth Analg, 2002. 95: 287-293, table of contents.

53. Schneeweiss S., Seeger J. D., Landon J.Walker A. M., Aprotinin during coronary-artery bypass grafting and risk of death. N Engl J Med, 2008. 358: 771-783.

54. Shaw A. D., Stafford-Smith M., White W. D., PhillipsBute B., Swaminathan M., Milano C., Welsby I. J., Aronson S., Mathew J. P., Peterson E. D.Newman M. F., The effect of aprotinin on outcome after coronaryartery bypass grafting. N Engl J Med, 2008. 358: 784793.

55. Tittel K., Hufnagel F.Schauwecker F., [Spiral drainage. An improved suction drainage]. Chirurg, 1980. 51: 185186.

56. Van Haelst I. M., Egberts T. C., Doodeman H. J., Traast H. S., Burger B. J., Kalkman C. J.Van Klei W. A., Use of serotonergic antidepressants and bleeding risk in orthopedic patients. Anesthesiology. 2010. 112: 631-636.

57. Vlahakes G. J., The value of phase 4 clinical testing. N Engl J Med, 2006. 354: 413-415.

58. Werner H. P., [Complications and risks of suction drainage]. Z Gesamte Hyg, 1990. 36: 94-99.

59. Willett K. M., Simmons C. D.Bentley G., The effect of suction drains after total hip replacement. J Bone Joint Surg Br, 1988. 70: 607-610. 
60. Wolter D., Burri C., Kinzl L.Muller A., [The change of physical properties of plastics (polyoxymethylenecopolymer, polyethyleneterephthalate, polyethylene, polytetrafluorethylene) after animal implantation and autoclavation (author's transl)]. Arch Orthop Unfallchir, 1976. 86: 291-302.

61. Zufferey P. J., Miquet M., Quenet S., Martin P., Adam P., Albaladejo P., Mismetti P.Molliex S., Tranexamic acid in hip fracture surgery: a randomized controlled trial. $\mathrm{Br} \mathrm{J}$ Anaesth. 2010. 104: 23-30.
Received: October 14, 2010 / Accepted: October 22, 2010

Address for correspondence:

PD Dr. med. Edwin Bölke

Klinik für Strahlentherapie und Radiologische Onkologie Heinrich-Heine-Universität Düsseldorf

Moorenstraße 5

40225 Düsseldorf

Germany

Tel.: $\quad+49-211-8117990$

Fax: +49-211-81118051

Email: boelke@med.uni-duesseldorf.de 